ISSN : $1410-7252$

Vol. 18 No. 01 Juni 2016

\title{
PERENCANAAN DAN PENGEMBANGAN DESA WISATA BERBASIS MASYARAKAT DENGAN MODEL PARTISIPATORY RURAL APPRAISAL (STUDI PERENCANAAN DESA WISATA GUNUNGSARI, KECAMATAN BUMIAJI, KOTA BATU)
}

\author{
Mohamad Nur Singgih ${ }^{1}$ \\ Nirwana $^{2}$ \\ Universitas Merdeka Malang
}

Korespodensi dengan Penulis:

Mohamad Nur Singgih: Telp:

E-mail: msingh.mlg@gmail.com

\begin{abstract}
Soetomo (2007), tourism development efforts which is local society oriented is still low and there are a lot of development failure because the policy holder still think partially. They only think about institution and sectorasl ego; society considered do not have the financial ability and quality skill to manage or participated directly in tourism nature and culture based activities. The aim of this research is 1) arrange the tourism rural activity area based on society sustainability tourism development. 2) Mapping the potentials, necessity and issues to plan the rural tourism development. 3) Empowering the societyto be responsible and play an active role toward planning and managing the rural tourism. This research is using qualitative descriptive with its variable rural tourism developmant plan. The data were collected by using observation, interview, documentation, and directional group discussion. The data analysis method is using appraisal rural partisipatory method consist of village history, seasonal calendar, daily lifes, village map, transect, livelihood analysis, and matrix ranking.
\end{abstract}

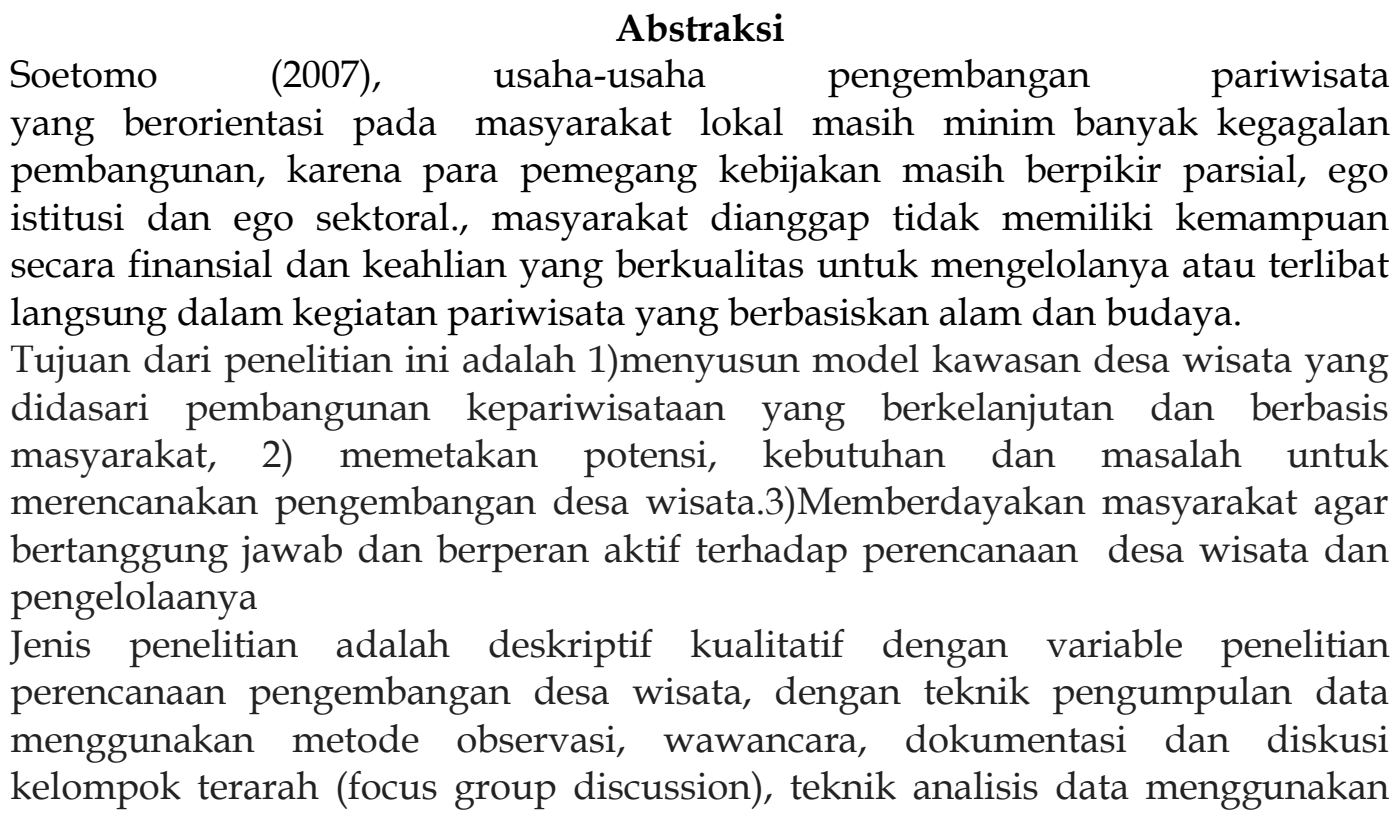


metode partisipatory rural appraisal yang terdiri dari village history, , seasonal calendar, daily lifes, village map, transect, livelihood analysis, matrix rangking,. Lokasi penelitian adalah desa gunungsari kecamatan Bumiaji, kota Batu. Hasil penelitian menunjukan desa Gunungsari Kecamatan Bumiaji Kota Batu memiliki potensi pengembangan desa wisata yang berbasis wisata alam dan budaya. Untuk wisata alam didukung beberapa objek wisata terdiri wisata air terjun, rafting,tubing, mountain bike, , petik mawar, petik apel,dan petik sayur . Untuk wisata budaya ditunjukan dengan banyaknya potensi budaya yang dilestarikan oleh masyarakat terdiri seni tari, seni bantengan, dan silat. Hasil pemetaan meliputi 1) hasil pemetaan tata guna lahan $42,21 \%$ ladang, 39,9\% sawah irigasi dan $20,5 \%$ pemukiman, 2)hasil pemetaan mata pecaharian $20,07 \%$ peternak sapi, $18,5 \%$ petani sayur, 9,08 \% peternak kambing dan 8,73\% petani mawar,3) hasil pemetaan atraksi terdiri dari wisata air terjun, rafting,tubing, mountain bike, , petik mawar, petik apel,dan petik sayur, dan budaya.4) hasil pemetaan infrastruktur menunjukkan air, listrik, jaringan telekomunikasi mendukung pengembangan desa wisata 5) hasil pemetaan fasilitas menunjukkan terdapat home stay, restaurant, usaha makanan untuk oleh-oleh wisatawan mendukung pengembangan desa wisata 6) hasil kajian aksesibilitas menujukkan lokasi destinasi dicapai dengan kendaraan umum dan pribadi 7) Hasil kajian kelembagaan desa, sumber daya manusia di lembaga desa sangat potensial dalam perencanaan dan pengembangan desa wisata 8) hasil kajian dampak sosial ekonomi menunjukan dampak sosial yang negatif yang perlu diantisipasi, sedangkan dampak ekonomi positif dalam meningkatkan pertumbuhan ekonomi desa..

Kata Kunci : Partisipatory, Rural, Destinasi

Era otonomi daerah sebagai implikasi dari berlakunya UU No. 32 tahun 2004, memberikan peluang bagi setiap pemerintah kabupaten/kota untuk merencanakan dan mengelola pembangunan daerahnya sendiri, UU No 10 Tahun 2009 tentang Kepariwisataan menyatakan bahwa masyarakat memiliki kesempatan yang sama dan seluas-luasnya untuk berperan serta dalam penyelenggaraan kepariwisataan. Peran serta masyarakat dalam memelihara sumber daya alam dan budaya yang dimiliki merupakan andil yang besar dan berpotensi menjadi daya tarik wisata.

Desa Gunungsari adalah salah satu desa yang berada dikecamatan Bumiaji kota Batu yang memiliki potensi alam dan budaya yang dapat dikembangkan sebagai desa wisata. Potensi sebagai daya dukung untuk pengembangan desa wisata terdiri dari dukungan infrastruktur, fasilitas dan aksesibilitas untuk mencapai objek wisata alam yang dapat menarik kunjungan wisatawan meliputi air terjun, kebun mawar dan kebun sayur 
dan beberapa kesenian yang di lestarikan oleh masyarakat Beberapa potensi daya tarik wisata yang dimiliki masih belum dikelola secara optima karena belum adanya perencanaan pengembangan desa wisata yang memadai. Disisi lain dukungan pemerintah daerah Kota Batu untuk mengembangkan desa Gunungsari sebagai desa wisata, memerlukan model yang sesuai agar pengembangan desa wisata ini dapat lestari dan berkesinambungan.

Menurut Nurmawati dalam Febiona (2012), pengembangan pariwisata daerah ditujukan untuk mengembangkan potensi lokal yang bersumber dari alam, sosial budaya ataupun ekonomi guna memberikan kontribusi bagi pemerintah daerah, sekaligus meningkatkan kesejahteraan masyarakat. Sedangkan Soetomo (2007), usahausaha pengembangan pariwisata yang berorientasi pada masyarakat lokal masih minim banyak kegagalan pembangunan, karena para pemegang kebijakan masih berpikir parsial, ego istitusi dan ego sektoral., masyarakat dianggap tidak memiliki kemampuan secara finansial dan keahlian yang berkualitas untuk mengelolanya atau terlibat langsung dalam kegiatan pariwisata yang berbasiskan alam dan budaya.

Penentuan model strategi dalam perencanaan dan pengembangan desa wisata sangatlah penting dilakukan dengan tujuan untuk mendapatkan model pengembangan desa wisata yang sesuai dengan karakteristik masyarakat dan kesinambungannya. Model partsipatory rural appraisal (PRA) merupakan salah satu model yang tepat untuk studi perencanaan dan pengembangan desa Gunungsari sebagai desa wisata berbasis masyarakat.Menurut Chambers (1992) Model partisipatory rural apprasila (PRA) merupakan salah satu model yang dapat digunakan mengkaji keadaan atau kondisi desa dengan melibatkan partisipasi masyarakat untuk menyusun perencanaan dan pengembangan desa wisata.. Perumusan masalahnya adalah “Bagaimana strategi merencanakan dan mengembangkan desa wisata berbasis masyarakat dengan model partisipatory rural appraisal (PRA)". 
Tujuan dari penelitian ini adalah 1)menyusun model kawasan desa wisata yang didasari pembangunan kepariwisataan yang berkelanjutan dan berbasis masyarakat, 2) memetakan potensi, kebutuhan dan masalah untuk merencanakan pengembangan desa wisata.3)Memberdayakan masyarakat agar bertanggung jawab dan berperan aktif terhadap perencanaan desa wisata dan pengelolaannya.

\section{METODE PENELITIAN}

Jenis penelitan ini adalah peneltian diskriptif kualitatif yang bertujuan untuk mengumpulkan informasi aktual secara rinci yang melukiskan gejala yang ada, mengindetifikasi masalah atau memeriksa kondisi dan praktekpraktek untuk menyusun perencanaan pengembangan desa wisata. Operasional variabel penelitian adalah perencanaan pengembangan desa wisata yang terdiri 1)Kajian sejarah desa adalah kajian untuk mengungkap kembali sejarah berdasarkan penuturan masyarakat sendiri. dimulai dari peristiwaperistiwa yang terjadi pada masa lampau yang masih dapat diingat, sampai dengan peristiwa-peristiwa saat ini.2) Kajian tata guna lahan dan mata pencaharian adalah kajian terkait $t$ penggunaan tata guna lahan desa serta terkait matapencaharian penduduk untuk mendukung pengembangan desa wisata.3)Kajian sarana dan prasarana pariwisata desa adalah kajian terkait dukungan atraksi, even,budaya, fasilitas dan aksesibilitas dalam pengembangan desa wisata. 4)Kajian kelembagaan adalah kajian terkait peran dan fungsi kelembagaan di desa dalam mendukung pengembangan pariwisata. 5)Kajian dampak sosial dan ekonomi pariwisata adalah kajian peningkatan pendapatan dan kesejahteraan masyarakat serta dampak sosial dari pengembangan pariwisata desa

Model penelitian ini menggunakan model partisipatory rural appraisal (PRA) untuk menyusun perencanaan dan pengembangan desa wisata dengan desain sebagai berikut 


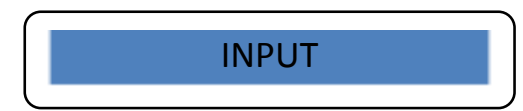

1. Penyusunan Tim PRA

2. Pelatihan Tim PRA

3. Pembuatan Desain Kegiatan PRA (Kajian Tourism)

4. Desk Study

\section{PROSES}

1. Diskusi Penggalian Informasi

2. Pendokumentasian Hasil Diskusi

3. Presentasi Hasil Diskusi

4. Perumusan Hasil Diskusi
1. Kajian Sejarah Desa

2. Kajian tata guna lahan dan Mata pencaharian penduduk

3. Kajian Sarana dan Prasarana Pariwisata Desa

4. Kajian Kelembagaan

5. Kajian Dampak Sosial dan Ekonomi Pariwisata Desa
( 
kecamatan Bumiaji, kota Batu Malang.

Desa Gunungsari terletak di antara bukit Panderman untuk bagian selatan dan Gunung Arjuna disebelah utara dengan ketinggian 1000 diatas permukaan laut. Dengan udara yang sejuk suhu $18-25^{\circ} \mathrm{C}$, view yang indah yang letaknya di lereng bukit gunung Banyak menjadi potensi desa yang dapat dikembangkan sebagai desa wisata. Luas wilayah desa Gunungsari 318,833 ha $\left(4,106 \mathrm{~km}^{2}\right)$ dengan peruntukan :

Tabel 1. Tata Guna Wilayah Desa Gunungsari

Kecamatan Bumiaji, Kota Batu Malang

\begin{tabular}{|c|l|c|}
\hline NO & \multicolumn{1}{|c|}{ WILAYAH } & LUAS \\
\hline 1 & Sawah irigasi teknis & 127,496 \\
\hline 2 & Sawah irigasi semi & 6 ha \\
\hline 3 & Tegal/Ladang & 134,385 \\
\hline 4 & Pemukiman & 65,433 \\
\hline 5 & Tanah kas Desa & 6,916 \\
\hline 6 & Lapangan & 1,122 \\
\hline 7 & Perkantoran $\quad /$ & 0,701 \\
\hline 8 & Jalan & 5 ha \\
\hline 9 & Lainnya & 0,823 ha \\
\hline 10 & Hutan produksi & \\
\hline
\end{tabular}

Sumber : Data Profil Desa, 2014

Potensi alam desa Gunungsari yang dapat menarik kunjungan wisatawan meliputi pemandangan alam yang indah, udara yang segar dan sejuk, air terjun, sungai, hutan. Potensi daya tarik (atraksi) lain bagi wisatawan adalah petik bunga, petik apel, petik jeruk, perah susu, petik sayur. Struktur pembagian wilayah desa Gunungsari dibagi menjadi 10 pedusunan yaitu Dusun Prambatan, Dusun Pagergunung, Dusun Kapru, Dusun Kandangan, Dusun Talangrejo, Dusun Brumbung, Dusun Ngebruk, Dusun Jantur, Dusun Claket, Dusun Brau.

\section{Pemetaan Mata Pencaharian Penduduk}

Dalam perencanaan desa wisata diperlukan kajian untuk memetakan matapencaharian atau jenis usaha yang dikembangkan penduduk. Hal ini bermanfaat untuk melihat potensi usaha yang dapat dijadikan atraksi yang ditawarkan kepada wisatawan atau mendukung pengembangaan desa wisata di desa Gunungsari. Kondisi alam desa Gunungsari dengan struktur tanahnya yang subur serta dukungan iklim yang sejuk sangat cocok digunakan untuk pertanian dan peternakan. Hasil pemetaan jenis usaha yang dikembangkan oleh 
ISSN : $1410-7252$

Vol. 18 No. 01 Juni 2016

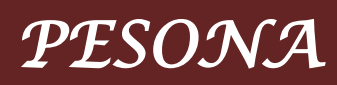

penduduk desa Gunungsari sebagai berikut :

Tabel 2. Jenis Mata Pencaharian

Penduduk Desa Gunungsari

Kecamatan Bumiaji, Kota Batu-

Malang

\begin{tabular}{|c|c|c|c|}
\hline $\begin{array}{l}\mathbf{N} \\
\mathbf{0}\end{array}$ & Jenis Usaha & $\begin{array}{l}\text { Juml } \\
\text { ah }\end{array}$ & $\begin{array}{c}\text { Prosent } \\
\text { ase }\end{array}$ \\
\hline 1 & Ternak sapi & 230 & $20.07 \%$ \\
\hline 2 & Petani sayur & 208 & $18.15 \%$ \\
\hline 3 & Ternak Kambing & 104 & $9.08 \%$ \\
\hline 4 & Petani mawar & 100 & $8.73 \%$ \\
\hline 5 & $\begin{array}{l}\text { Petani bunga non } \\
\text { mawar }\end{array}$ & 85 & $7.42 \%$ \\
\hline 6 & Mracang & 73 & $6.37 \%$ \\
\hline 7 & Pedagang sayur & 59 & $5.15 \%$ \\
\hline 8 & $\begin{array}{l}\text { Pedagang } \\
\text { makanan }\end{array}$ & 42 & $3.66 \%$ \\
\hline 9 & Lainnya & 37 & $3.23 \%$ \\
\hline 10 & Pedagang bunga & 32 & $2.79 \%$ \\
\hline 11 & Petani apel & 30 & $2.62 \%$ \\
\hline 12 & Jasa angkutan & 29 & $2.53 \%$ \\
\hline 13 & pedagang ternak & 16 & $1.40 \%$ \\
\hline 14 & $\begin{array}{l}\text { Layanan air } \\
\text { minum }\end{array}$ & 14 & $1.22 \%$ \\
\hline 15 & Penjahit & 9 & $0.79 \%$ \\
\hline 16 & Produksi makanan & 9 & $0.79 \%$ \\
\hline 17 & Jasa pendidikan & 8 & $0.70 \%$ \\
\hline 18 & Pedagang buah & 7 & $0.61 \%$ \\
\hline 19 & Pedagang pakaian & 7 & $0.61 \%$ \\
\hline
\end{tabular}

\begin{tabular}{|r|l|r|r|}
\hline 20 & Petani jeruk & 7 & $0.61 \%$ \\
\hline 21 & Sewa rumah & 5 & $0.44 \%$ \\
\hline 22 & Jual beli mobil & 4 & $0.35 \%$ \\
\hline 23 & Tani rumput gajah & 4 & $0.35 \%$ \\
\hline 24 & Ternak Kelinci & 4 & $0.35 \%$ \\
\hline 25 & $\begin{array}{l}\text { Pedagang bibit } \\
\text { tanaman }\end{array}$ & 3 & $0.26 \%$ \\
\hline 26 & Service motor & 3 & $0.26 \%$ \\
\hline 27 & Bengkel mobil & 2 & $0.17 \%$ \\
\hline 28 & $\begin{array}{l}\text { Industri alat rmh } \\
\text { tangga }\end{array}$ & 2 & $0.17 \%$ \\
\hline 29 & Jasa Pijat & 2 & $0.17 \%$ \\
\hline 30 & Pedagang Saprodi & 2 & $0.17 \%$ \\
\hline 31 & Petani Sengon & 2 & $0.17 \%$ \\
\hline 32 & Budidaya Bibit & 1 & $0.09 \%$ \\
\hline 33 & Jeruk & 1 & $0.09 \%$ \\
\hline 34 & Jual Jamu & 1 & $0.09 \%$ \\
\hline 35 & Petani kopi & $0.09 \%$ \\
\hline 36 & Petani lebah & $0.09 \%$ \\
\hline 37 & Produksi souvernir & 1 & $0.09 \%$ \\
\hline 38 & Ternak ulat & & \\
\hline & & 1 & \\
\hline
\end{tabular}

Sumber data : Data UMKM Desa

Gunungsari, BPS 2014

Dari table 2. menunjukkan jenis usaha yang banyak dikembangkan oleh masyarakat desa Gunungsari; ternak sapi 20,07 \%, petani sayur 18,5 \%, , ternak kambing 9,08 \%, petani bunga mawar $8,73 \%$,petani bunga non 
mawar $7.42 \%$. Mracang 6,73 \% dan pedagang sayur $5,15 \%$ selain itu jenis usaha lainnya dibawah $5 \%$. Hasil pemetaan menunjukan basis pertanian dan peternakan menjadi sangat penting sebagai jenis usaha yang banyak dikembangkan oleh masyarakat desa Gunungsari sehingga dalam perencanaan pengembangan desa wisata, produk pertanian dan peternakan dapat dikemas sebagai salah satu daya tarik atau produk wisata yang mampu menarik wisatawan. Pemetaan jenis usaha penduduk berdasarkan potensi wilayah per dusun desa Gunungsari Batu:

a) Dusun Brau, jenis usaha yang dikembangkan oleh penduduk dusun Brau ; 92 kk ( kepala keluarga) $(91,0 \%)$, berternak sapi baik ternak sapi perahan dan ternak penggemukan sapi,6 kk $(6,0 \%)$ mracang . Jenis usaha yang banyak dikembangkan penduduk dusun Brau adalah bidang peternakan khususnya ternak sapi.

b) Dusun Brumbung jenis usaha yang dikembangkan oleh penduduk dusun Brumbung 38 kk (37,25 \%) bertani mawar, 11 kk $(10,78 \%)$ bertani sayur, 9 kk $(8,82 \%)$ berternak sapi, 8 kk (7,84\%) beternak kambing, 6 kk $(5,88 \%)$ mracang sedangkan usaha lain dibawah $5 \%$. Jenis usaha yang banyak dikembangkan penduduk dusun brumbung pada bidang pertanian khusunya bertani mawar dan sayur.

c) Dusun Claket, jenis usaha yang dikembangkan oleh penduduk dusun Claket 31 kk $(29,25 \%)$ beternak sapi, 30 kk (28,30\%) beternak kambing, 14 kk (13,21\%) bertani sayur, 9 kk (8,49\%) pedagang sayur sedangkan usaha lain hanya dibawah $5 \%$. Jenis usaha yang banyak dikembangkan penduduk dusun brumbung pada bidang peternakan sapi dan kambing.

d) Dusun Jantur, jenis usaha yang dikembangkan oleh penduduk dusun Jantur 58 kk $(39,19 \%)$ beternak sapi, 30 kk $(20,27 \%)$ bertani sayur, $11 \mathrm{kk}(7,43 \%)$ pedagang sayur, 9 kk (6,08\%) mracang, 8 kk (5,41\%)beternak kambing sedangkan usaha lain 
dibawah $5 \%$. Jenis usaha yang banyak dikembangkan penduduk dusun brumbung pada bidang peternakan sapi dan kambing, sedangkan untuk bidang pertanian bertani sayur.

e) Dusun Kandangan, jenis usaha yang dikembangkan oleh penduduk dusun Kandangan; 63 kk (28,8 \%) bertani sayur, 38 kk $(17,4 \%)$ bertani bunga non mawar ((krisan, pikok, pucuk merah, tricolor dll), $26 \mathrm{kk} \quad(11,9 \%)$ berternak kambing, 13(5,9\%) bertani mawar, $11 \quad(5,0 \quad \%)$ pedagang sayur sedangkan usaha lainnya dibawah $5 \%$. Jenis usaha yang banyak dikembangkan penduduk dusun Kandangan berbasis pertanian.

f) Dusun Prambatan, jenis usaha yang dikembangkan oleh penduduk dusun Prambatan; 9 kk $(21,4 \%)$ bertani bunga non mawar, 4 kk (9,5\%) bertani apel, 4 kk (9.5\%) mracang, 4 kk (9,5\%) jual makananan, sedangkan usaha lain hanya dibawah $5 \%$

g) Dusun Talangrejo, jenis usaha yang dikembangkan oleh penduduk dusun Talangrejo; 21 kk (21,4\%)bertani mawar, 16 kk $(13,1 \%)$ bertani sayur, 13 kk $(10,7 \%)$ beternak sapi,12 kk(9,8 \%) beternak kambing, 10 (8,2 \%) pedagang makanan, $8 \mathrm{kk}(6,6 \%)$ pedagang sayur, $7 \mathrm{kk} \quad(5,7 \%)$ bertani bunga non mawar dan 7 $(5,7 \%)$ mracang sedangakan usaha lain dibawah $5 \%$. Jenis usaha yang dikembangkan penduduk desa Talangrejo lebih didominasi oleh pertanian dan peternakan

h) Dusun Ngebruk, jenis usaha yang dikembangkan oleh penduduk dusun Ngebruk; 16 kk (25,8\%)bertani mawar, 15 kk (24,2 \%)berternak sapi, $10 \mathrm{kk}$ (16,1\%) berternak kambing,7 kk (11,3\%) bertani sayur, 4 (6.5\%) pedagang mracang, sedangakan usaha lain dibawah $5 \%$. Jenis usaha yang dikembangkan penduduk desa Ngeburk lebih banyak dibidang pertanian dan peternakan

i) Dusun Pagergunung, jenis usaha yang dikembangkan oleh penduduk dusun Pagergunung 36 kk (26,3 \%) bertani sayur, 12 kk $(8,8 \%)$ mracang, 8 kk (5,8\%) pedagang ternak, $7 \mathrm{kk} \quad(5,1 \%)$ 
pedagang sayur, $7 \mathrm{kk} \quad(5,1 \%)$ pedagang makanan, $7 \mathrm{kk}(5,1 \%)$ jasa angkutan sedangkan usaha lain hanya dibawah $5 \%$. Jenis usaha pertanian khusunya sayur menjadi usaha yang banyak dikembangkan oleh penduduk dusun Pagergunung.

j) Dusun Kapru, Jenis usaha yang banyak dikembangkan oleh penduduk dusun Kapru 27 kk (25 \%) bertani sayur, 17 kk (15,7\%) bertani apel, 15 kk (13,9\%) bertani bunga non mawar (krisan, pikok, pucuk merah, tricolor dll), 7(6.5\%) bertani mawar sedangkan usaha lainnya dibawah $5 \%$.

\section{Pemetaan Kalender Musim Untuk} Hasil Pertanian dan Peternakan

Kalender musim digunakan untuk mengkaji kegiatan dan keadaan yang terjadi berulang dalam kurun waktu tertentu bisanya periode 1 tahun contoh kajian hasil pertanian dan peternakan yang merupakan jenis usaha yang banyak dikembangkan penduduk desa Gunungsari . Manfaat kajian ini untuk mengetahui masalah dan potensi hasil produk pertanian dan

peternakan.

Tabel 3. Kalender Musim Hasil Pertanian dan Peternakan

Desa Gunungsari, Kecamatan Bumiaji, Kota Batu Malang, 2015

\begin{tabular}{|c|l|c|c|c|c|c|c|c|c|c|c|c|c|c|}
\hline \multirow{2}{*}{ No } & \multirow{2}{*}{ Jenis Produk } & \multicolumn{7}{|c|}{ Hasil } & & \multicolumn{7}{|c|}{ Bulan } \\
\cline { 5 - 11 } & & & 1 & 2 & 3 & 4 & 5 & 6 & 7 & 8 & 9 & 10 & 11 & 12 \\
\hline 1 & Bunga mawar & 100.000 potong/hari & & & & & & & & & & & & \\
\hline 2 & Susu Sapi & 6000 liter/hari & & & & & & & & & & & & \\
\hline 3 & Sayuran & 3000 kg/hari & & & & & & & & & & & & \\
\hline 4 & Kelinci & 500 ekor/hari & & & & & & & & & & & & \\
\hline 5 & Kambing & 1000 ekor/bulan & & & & & & & & & & & & \\
\hline 6 & Sari apel & 15 pax/hari & & & & & & & & & & & & \\
\hline 7 & Apel & $100-200$ ton/musim & & & & & & & & & & \\
\hline 8 & Jeruk & $50-100$ ton/musim & & & & & & & & & & & \\
\hline
\end{tabular}

Sumber : Hasil FGD Kalender Musim desa Gunungsari 2015 
a) Bunga mawar menjadi komoditi yang ditanam sepanjang tahun tanpa mengenal musim dengan rata-rata produksi 100.000 potong per hari dengan pemasaran melalui pedagang bunga dengan harga Rp 1500 /tangkai potong dengan area pemasaran Jakarta, Solo dan Malang. Untuk pasar wisatawan petik mawar menjadi suatu daya tarik wisata dengan memberi kebebasasan wisatawan untuk memetik bunga mawar dengan harga Rp 2500 per tangkai (potong). Masalah yang dihadapi petani mawar adalah biaya perawatan semakin mahal disisi lain harga mawar di pasar cenderung tetap.

b) Susu sapi merupakan salah satu komoditi andalan yang menjadi penopang kehidupan penduduk desa gunungsari dengan hasil produksi susu sapi rata-rata 50006000 per hari. Masalah yang dihadapi penduduk adalah harga susu sapi yang rendah sekitar Rp 4600/liter tidak sesuai ongkos produksi untuk makanan ternak sapi yang mengalami kenaikan setiap tahunnya. Berdasarkan potensi ternak sapi yang ada di desa Gunungsari Batu, pengembangan produk turunan dari susu sapi seperti minuman susu yoghurt dan pembuatan keju dari susu sapi menjadi kebutuhan yang dapat dikembangkan sebagai solusi nilai tambah produk susu sapi untuk meningkatkan pendapatan peternak sapi. Hal ini juga menjadi daya tarik wisata bagi wisatawan untuk melihat cara membuat yoghurt dan keju untuk meningkatkan kesejahteraan peternak sapi.

c) Sayuran yang terdiri dari wortel, kentang, sawi, tomat, cabai, kobis, prei, seledri, buncis, dan kapri, merupakan komoditas sayuran yang dihasilkan petani sayur di desa Gunungsari Batu. Hasil produksi sayuran rata-rata 3000 $4000 \mathrm{~kg} /$ hari yang di pasarkan di pasar lokal Batu. Harga sayuran berfluktuasi sesuai dengan kondisi hasil panen, jika hasil panen melimpah harga cenderung turun,sedangan jika hasil panen kurang baik cenderung harga sayuran naik. Petik sayuran merupakan salah satu potensi 
wisata yang telah dikembangkan petani sayur di desa Gunungsari Batu dengan mengajak wisatawan untuk memanen sayuran langsung dari kebun petani.

d) Kambing merupakan komoditas ternak yang dihasilkan oleh peternak kambing di desa Gunugsari Batu. Ternak kambing merupakan salah satu penopang kehidupan penduduk Gunungsari batu dengan rata-rata hasil produksi per bulan 1000 ekor/bulan.

e) Kelinci merupakan salah satu komoditas hasil peternakan di desa Gunungsari yang dikembangkan oleh sebagian penduduk untuk memenuhi permintaan daging kelinci yang tinggi di kota Batu. Permintaan daging kelinci dipengaruhi oleh perkembangan kuliner sate kelinci yang banyak ditemukan dikota Batu. Kemampuan produksi kelinci di desa Gunungsari rata-rata 500 ekor /hari.

f) Apel merupakan hasil produksi pertanian penduduk desa Gunungsari yang siklus panennya adalah musiman.Jenis apel yang

dihasilkan adalah apel Manalagi dan apel Anna. Hasil produksi apel rata-rata 100 - 200 ton/ musim. Siklus panen apel adalah 6 bulan sekali.Pemasaran buah apel di pasar lokal Batu. Hasil turunan produk apel adalah minuman sari apel yang mulai dikembangkan oleh penduduk desa Gunungsari dengan hasil rata-rata 20 pax per hari. Petik apel juga menjadi potensi wisata yang saat ini dikembangkan petani apel di desa Gunungsari dengan harga Rp 30.000 per $\mathrm{kg}$ untuk hasil petik wisatawan

g) Jeruk merupakan hasil produksi pertanian yang dikembangkan oleh penduduk desa Gunungsari. Jenis yang dihasilkan oleh petani jeruk desa Gunungsari adalah jeruk keprok batu 55 dengan hasil produksi rata-rata $50-100$ ton /musim. Siklus panen jeruk dilakukan satu tahun sekali selama 2 bulan. Pemasaran buah jeruk dipasar lokal kota Batu.

Pemetaan Daya Tarik (Atraksi) Wisata 
Desa Gunungsari memiliki banyak daya tarik wisata yang sangat potensial untuk mendukung pengembangan desa wisata. Daya tarik wisata yang didukung potensi alam di desa Gunungsari yaitu : Air terjun (Cuban )kembar dan Cuban Cendana di dusun Jantur, Rafting dan Tubing di sungai Brantas, Montain bike cross, Camping atau Outbond, Paralayang, Petik Mawar, Petik Apel, Petik Sayur dan Peras Susu sapi. Daya tarik wisata yang saat ini dikembangkan menjadi daya tarik wisata desa Gunungsari adalah petik Mawar, petik Sayur dan petik Apel dengan konsumen wisatawan nusantara wisatawan mancanegara. Beberapa persoalan dalam pengembangan daya tarik (atraksi): :

1. Air terjun (Cuban) kembar dan Cendana didusun jantur belum dapat dikembangkan menjadi daya tarik wisata karena persoalan akses jalan yang belum ada dan area air terjun (Cuban) masih dimiliki oleh perorangan.

2. Rafting dan Tubing di sungai Brantas terkendala dengan debit air yang terlalu kecil saat musim kemarau sehingga pengelolaan rafting hanya dikelola secara musiman.

3. Montain bike adalah wisata dengan menggunakan motor trail bagi para crosser yang menyukai tantangan mengendarai motor dengan medan atau lintasan yang cukup ekstrem. Persoalanannya untuk wisata ini belum ada fasilitas pendukung seperti rent motor dan wadah pengelola motor trail belum terbentuk

4. Camping atau outbond didusun Jantur belum didukung fasilitas alat yang memadai untuk outbond.

5. Paralayang telah menjadi atraksi wisata yang dikelola desa Pujon, namun dari pemetaaan wilayah atraksi wisata berbatasan dengan wilayah dusun Brau desa Gunungsari Batu diperlukan pembukaan akses untuk menuju lokasi paralayang dari dusun Brau.

\section{Pemetaan Prasarana Wisata}

Potensi

prasarana

(infrastruktur)wisata di desa 
Gunungsari

Batu

untuk

pengembangan desa wisata adalah

a. Jaringan telekomunikasi, provider telekomonukasi yang tersedia dan memiliki sinyal yang cukup kuat di desa Gunungsari adalah jaringan telekomunikasi axiata, telkomsel dan indosat. Jaringan telekomunikasi yang baik akan membantu wisatawan dalam berkomunikasi dengan keluarga, teman atau pihak lainnya melalui gadged atau handphone.

b. Ketersediaan air, kuantitas air yang cukup sangat diperlukan untuk wisatawan. Ketersediaan air di desa Gunungsari sangat mencukupi untuk memenuhi kebutuhan wisatawan yang mengunjungi desa wisata tersebut karena daerah Gunungsari Batu merupakan daerah konservasi air di wilayah Batu.

c. Listrik dan Energy, Kebutuhan listrik dalam pengembangan desa wisata harus dipertimbangan untuk mememnuhi kebutuhan wisatawan. Untuk jaringan dan energi listrik sudah lama masuk ke desa Gunungsari dengan rata-rata penggunaaan 450-1300 kwh per kepala rumah tangga.

d. Sistem pembuangan limbah kotoran, upaya untuk menjaga kebersihan dan kenyamanan wisatawan perlu dukungan system pembuangan limbah kotoran yang memadai. Peternak sapi di desa Gunungsari belum mengelola limbah kotoran sapi secara baik, hal ini menjadi tantangan bagi masyarakat untuk dapat mengelola limbah kotoran sapi secara baik dalam mendukung pengembangan desa wisata, agar wisatawan yang berkunjung di desa Gunungsari merasa nyaman tidak terganggu bau limbah kotoron sapi.

e. Jalan - Infrastruktur jalan sangat diperlukan untuk mendukung aksesibilitas atau kemampuan untuk mencapai suatu tempat tujuan wisata. Kondisi jalan menuju desa 
Gunungsari relative kecil dan sempit sehingga untuk kendaraan besar (bus) tidak bisa masuk ke desa. Kondisi jalan $60 \%$ cukup baik dan $40 \%$ kurang baik.

Pemetaan Sarana atau Fasilitas Wisata

Fasilitas wisata yang mendukung pengembangan desa wisata di desa Gunungsari terdiri dari :

a. Home stay atau guest house yang terdapat 5 buah home stay yang disewakan kepada wisatawan. Persoalan yang dihadapi pemilik home stay adalah sepinya tamu karena kurangnnya promosi desa Gunungsari sebagai desa wisata.

b. Restauran dan Kafe Gunung yang menyajikan menu khusus khas pegunungan yang terletak diarea sawah dengan view yang indah.

c. Usaha makanan untuk oleholeh wisatawan dengan produksi kripik Nangka, kripik Apel, kue Ladu, minuman sari Apel. d. Pemandu wisata juga berperan sebagai travel agen yang membawa wisatawan untuk melakukan petik Mawar, petik Apel dan petik Sayur yang berarsal dari tamu hotel di Batu maupun wisatawan yang langsung datang ke Batu.

e. Persewaan mobil (rent car) yang menyediakan fasilitas mobil untuk melayani tamu yang datang ke desa Gunungsari Batu.

Beberapa fasilitas yang belum tersedia dan perlu disediakan untuk mendukung pengembangan desa wisata di desa Gunungsari Batu adalah :

a. Area parkir untuk sarana parkir kendaraan wisatawan.

b. Pasar buah dan sayur untuk menampung hasil pertanian dan sarana belanja wisatawan .

\section{Pemetaan Aksesibilitas Destinasi} Wisata

Kemudahan untuk mencapai destinasi wisata menjadi perhatian wisatawan dalam memutuskan perjalanan wisatanya. Beberapa indicator yang digunakan untuk mengukur kemudahan menuju tujuan wisata 
adalah, model transportasi yang digunakan, jarak tempuh dan kondisi dalam perjalanan.

a) Moda transportasi yang digunakan untuk menuju desa Gunungsari dapat menggunakan kendaraan pribadi atau transportasi umum. Untuk transportasi umum adalah dengan menggunakan bus sampai terminal kota Batu dilanjutkan mikrolet dan ojek motor untuk sampai tujuan di desa Gunungsari Batu, kondisi jalan cukup baik dan aman.

b) Jarak tempuh menuju desa Gunungsari Batu berdasar data orbitas :

- Jarak Desa Gunungsari ke pusat kota Batu 4,5 Km dengan waktu tempuh 15 menit
- Jarak Desa Gunungsari ke pusat kota Malang $30 \mathrm{Km}$ dengan waktu tempuh 45 menit

- Jarak Desa Gunungsari ke Ibu Kota Propinsi Jawa Timur 111,5 Km ,dengan waktu tempuh 3 jam

c) Kondisi perjalanan menuju desa Gunungsari dari ibu kota propinsi Jawa Timur pada hari kerja akan terjadi pelambatan perjalan saat memasuki ds Purwosari kabupaten Malang

\section{Kajian Kelembagaan}

Kajian kelembagaan digunakan untuk melihat sejauh mana masalah dan potensi lembaga yang terdapat di desa Gunungsari dalam pengembangan desa wisata.. Berikut lembaga desa yang aktif memafasilitasi kegiatan di desa Gunungsari

Tabel 4. Masalah dan Potensi Kelembagaan dalam Pengembangan Desa Wisata

\begin{tabular}{|c|c|l|l|}
\hline No & Lembaga & \multicolumn{1}{|c|}{ Masalah } & \multicolumn{1}{|c|}{ Potensi } \\
\hline 1. & $\begin{array}{c}\text { Pemerintah Desa dan } \\
\text { BPD }\end{array}$ & $\begin{array}{l}\text { Pemerintah desa masih mengalami } \\
\text { kesulitan dalam mengembangkan } \\
\text { akses dan fasilitas wisata karena } \\
\text { persoalan pembebasan lahan dan } \\
\text { terbatasannya anggaran yang tersedia }\end{array}$ & $\begin{array}{l}\text { Perangkat desa } \\
\text { lengkap } \\
\text { Fasilitas tersedia } \\
\text { Anggaran dana desa }\end{array}$ \\
\hline 2. & LPMD & $\begin{array}{l}\text { Belum memiliki rencana strategis dan } \\
\text { komprehensip dalam pengembangan } \\
\text { desa wisata }\end{array}$ & $\begin{array}{l}\text { Pengurus lengkap } \\
\text { Tenaga pengurus } \\
\text { potensial }\end{array}$ \\
\hline 3. & POKDARWIS & $\begin{array}{l}\text { Kelompok sadar wisata } \\
\text { (POKDARWIS) belum mengelola }\end{array}$ & $\begin{array}{l}\text { Banyak anggota } \\
\text { kelompok sadar }\end{array}$ \\
\hline
\end{tabular}


ISSN : $1410-7252$

Vol. 18 No. 01 Juni 2016

\begin{tabular}{|c|c|l|l|}
\hline & \multicolumn{1}{|c|}{$\begin{array}{l}\text { potensi wisata secara optimal } \\
\text { karena kesibukan masing-masing } \\
\text { anggota kelompok } \\
\text { Dibutuhkan reorganisasi } \\
\text { pengurus dan penguatan kembali } \\
\text { kelompok untuk manajemen } \\
\text { pengelolaan destinasi }\end{array}$} & wisata yang potensial \\
\hline 4. & RT dan RW & $\begin{array}{l}\text { Belum memiliki usulan program dan } \\
\text { kegiatan terkait pengembangan desa } \\
\text { wisata dimasing-masing RT dan RW }\end{array}$ & $\begin{array}{l}\text { Pengurus RT dan RW } \\
\text { lengkap } \\
\text { SDM sangat potensial }\end{array}$ \\
\hline 5. & PKK & $\begin{array}{l}\text { Belum memiliki rencana aksi dalam } \\
\text { mendukung pengembangan desa } \\
\text { wisata }\end{array}$ & $\begin{array}{l}\text { Pengurus PKK } \\
\text { lengkap } \\
\text { SDM pengurus } \\
\text { potensial }\end{array}$ \\
\hline 6. & GAPOKTAN & $\begin{array}{l}\text { Kegiatan gabungan kelompok tani } \\
\text { (GAPOKTAN) masih sebatas sektor } \\
\text { pertaniannya dan memerlukan } \\
\text { penguatan kelompok untuk } \\
\text { memadukan sektor pertanian dengan } \\
\text { kegiatan pariwisata sebagai sektor } \\
\text { unggulan wisata }\end{array}$ & $\begin{array}{l}\text { Pengurus lengkap dan } \\
\text { failitas tersedia } \\
\text { SDM sangat Potensial }\end{array}$ \\
\hline
\end{tabular}

Sumber : Hasil FGD Tim PRA Desa Gunungsari, 2015

Kajian Dampak Sosial dan Ekonomi

\section{Pariwisata}

Hasil kajian pemetaan social dan ekonomi sebelum dan sesudah dilakukan pengembangan desa wisata sesuai dengan indicator Cohen (1980), hasil kajian tim PRA

Dampak sosial dari pengembangan desa wisata untuk tingat ketergantungan dengan masyarakat luar semakin tinggi (kurang baik), hubungan interpersonal antara anggota masyarakat semakin pudar (kurang baik), pola pembagian kerja semakin baik menggunakan manajemen modern (baik), penyimpangan sosial semakin meningkat (kurang baik), perkembangan kesenian dan budaya semakin berkembang (baik), ritme kehidupan semakin produktif (baik).

Tabel 6. Dampak Ekonomi Sebelum dan Susudah Pengembangan Desa Wisata

\begin{tabular}{|l|l|l|l|}
\hline No & \multicolumn{1}{|c|}{ Indikator } & \multicolumn{1}{|c|}{ Sebelum Pengembangan } & \multicolumn{1}{|c|}{ Sesudah Pengembangan } \\
\hline 1 & $\begin{array}{l}\text { Dampak terhadap } \\
\text { pendapatan masyarakat }\end{array}$ & $\begin{array}{l}\text { Pendapatan cukup, dari } \\
\text { sektor pertanian dan } \\
\text { peternakan }\end{array}$ & $\begin{array}{l}\text { Pendapatan tinggi, dari } \\
\text { berbagai sumber (dampak } \\
\text { baik) }\end{array}$ \\
\hline 2. & $\begin{array}{l}\text { Dampak terhadap } \\
\text { kesempatan kerja }\end{array}$ & $\begin{array}{l}\text { Kesempatan kerja lebih } \\
\text { dibanyak diserap oleh sektor } \\
\text { pertanian dan peternakan }\end{array}$ & $\begin{array}{l}\text { Kesempatan kerja lebih luas } \\
\text { diberbagai sektor, } \\
\text { khususnya disektor } \\
\text { pariwisata (dampak baik) }\end{array}$ \\
\hline
\end{tabular}


ISSN : $1410-7252$

Vol. 18 No. 01 Juni 2016

\begin{tabular}{|l|l|l|l|}
\hline 3. & $\begin{array}{l}\text { Dampak harga-harga } \\
\text { produk wisata }\end{array}$ & $\begin{array}{l}\text { Harga produk pertanian } \\
\text { untuk bunga dan peternakan } \\
\text { dan souvernir relatif murah }\end{array}$ & $\begin{array}{l}\text { Pengembangan desa wisata } \\
\text { akan mendorong produk } \\
\text { pertanian bunga, produk } \\
\text { peternakan dan souvernir } \\
\text { akan menjadi lebih tinggi } \\
\text { (dampak baik) }\end{array}$ \\
\hline 4. & $\begin{array}{l}\text { Dampak terhadap distribusi } \\
\text { pendapatan }\end{array}$ & $\begin{array}{l}\text { Distribusi pendapatan lebih } \\
\text { didominasi sektor pertanian } \\
\text { dan peternakan }\end{array}$ & $\begin{array}{l}\text { Distribusi pendapatan lebih } \\
\text { menyebar diberbagai sektor } \\
\text { seperti hotel, restaurant dan } \\
\text { industri makanan untuk } \\
\text { oleh-oleh wisawan (dampak } \\
\text { baik) }\end{array}$ \\
\hline 5. & $\begin{array}{l}\text { Dampak terhadap } \\
\text { kepemilikan tanah dan } \\
\text { property }\end{array}$ & $\begin{array}{l}\text { Kepemilikan tanah dan } \\
\text { property lebih banyak } \\
\text { dikuasai masyarakat lokal } \\
\text { pampak terhadap }\end{array}$ & $\begin{array}{l}\text { Dikuasai sebagian } \\
\text { pendatang dan investor } \\
\text { (dampak kurang baik) }\end{array}$ \\
\hline 6. & pemerimaan pendapatan \\
pemerintah desa kecil & $\begin{array}{l}\text { Penerimaan pendapatan } \\
\text { pemerintah desa meningkat } \\
\text { berasal dari kontribusi } \\
\text { restribusi wisata dan } \\
\text { pajak.(dampak baik) }\end{array}$ \\
\hline
\end{tabular}

Sumber : Hasil FGD Dampak Ekonomi dari Pengenbangan Desa wisata

Gunungsari, 2015

Dari hasil kajian dampak ekonomi dari pengembangan desa wisata yang meliputi dampak terhadap pendapatan masyarakat meningkat (baik), kesempatan kerja lebih lebih luas (baik), harga-harga produk wisata meningkat (baik), distribusi pendapatan semakin menyebar (baik), , dampak terhadap pendapatan pemerintah desa semakin meningkat (baik) , sedangkan dampak kepemilikan tanah dan property dari pengembangan desa wisata lebih banyak dikuasai pemilik modal atau investor (kurang baik).

\section{KESIMPULAN}

Berdasarkan hasil kajian pemetaan masalah, potensi dan kebutuhan dapat ditarik kesimpulan :

a. Berdasarkan tata penggunaan lahan $42,1 \%$ untuk ladang, 39,9 \% untuk sawah irigasi dan hanya 20,5 $\%$ menunjukan potensi lahan yang ada dapat mendukung pengembangan desa wisata.

b. Hasil kajian pemetaan mata pencaharian menunjukkan 20,07 \% sebagai peternak sapi, $18,05 \%$ sebagai petani sayur, 9,08 sebagai peternak kambing, dan 8,73\% sebagai petani mawar. Hal ini memberikan kerangka dalam pengembangan desa wisata sektor 
peternakan dan pertanian harus menjadi basis pengembangan produk wisata.

c. Hasil kajian pemetaan daya tarik atraksi masih banyak daya tarik wisata yang belum dikelola secara optimal untuk menarik wisatawan seperti air terjun, rafting, mountain bike, camping dan outbond karena persoalan hak milik tanah, akses jalan yang sulit dan pengelola wisata yang kurang serius dalam menanganinya.

d. Hasil kajian pemetaan infrastruktur wisata menunjukkan untuk air, listrik dan jaringan komunikasi yang tersedia sangat mendukung kenyamanan wisatawan untuk berkunjung di desa Gunungsari sedangakan saluran limbah untuk mengelola kotoran sapi menjadi masalah yang dapat menimbulkan ketidaknyaman kunjungan wisatawan sehingga perlu penanganan untuk pengembangan desa wisata.

e. Hasil kajian fasilitas wisata yang mendukung pengembangan desa wisata menunjukan fasilitasnya masih sangat minim, hanya terdapat 5 guest houst, 1 restaurant dan 5 idustri makanan sedangakan fasilitas lain seperti area parkir, toilet, pasar sayur dan buah, souvernir dan fasilitas lainnya menjadi kebutuhan yang harus dikembangan untuk mendukung pengembangan desa wisata.

f. Hasil kajian pemetaan aksesibilitas menunjukkan dalam kondisi normal bottle neck perjalanan wisatawan akan mengalami pelambatan di sekitar area purwosari smpai dengan kota malang, sedangkan dalam kondisi liburan panjang kemacetan terjadi sepanjang akses mulai masuk kabupaten malang sampai dengan akses ke batu akan terjadi kemacetan total sehingga perlu solusi untuk penangangan terintegrasi dari pemerintahan yang ada di malang raya (kota Batu, Kota Malang dan Kabupaten Malang)

g. Kajian kelembagaan menunjukan potensi dan masalah yang dihadapi oleh lembaga desa yang terdiri dari pemerintahan desa, BPD, LPMD, POKDARWIS, RT dan RW, GAPOKTAN dan PKK memiliki 
potensi sumber daya yang potensial dalam mendukung pengembangan desa wisata dengan sejumlah fasilitas dan pengurus yang lengkap, sedangkan masalah yang dihadapi adalah dibutuhkan penguatan kelembagaan untuk pemberdayaan dan pengembangan potensi wisata desa.

h. Kajian dampak sosial menunjukan adanya potensi sosial yang negative dari pengembangan desa wisata seperti ketergantungan dengan masyarakat luar semakin meningkat, hubungan interpersonal masyarakat semakin individual dan persoalan sosial yang timbul semakin meningkat sedangkan kajian ekonomi menunjukkan adanya potensi yang positif dari pengembangan desa wisata seperti peningkatan pendapatan, distribusi pendapatan yang merata, peningkatan peluang kerja dan kesempatan berusaha.

i. Pengembangan desa wisata harus menjadi komitmen seluruh pemangku kepentingan (stakeholder) meliputi komitmen seluruh lembaga desa seperti pemerintahan desa dan kabupaten, BPD, LPMD, POKDARWIS, GAPOKTAN, PKK Pengusaha, dan seluruh warga desa Gunungsari dengan menyusun rencana induk dan strategi pengembangan desa wisata.

\section{DAFTAR PUSTAKA}

Chambers, R. 1992, Rural Appraisal, Rapid,Relaxed, and Partisipatory Inst, Dev,Studies Univ Sussex, England

Febiona, 2012. Artikel Pengembangan Desa Wisata Untuk Meningkatkan Pendapatan Asli daerah diakses melalui indraculin.blogspot.com tanggal 18 Apri 2013

Handayani, Sri. "Penerapan Metode Penelitian Participatory Research Apraisal dalam Penelitian Permukiman Vernakular (Permukiman Kampung Kota)." Proceeding Seminar Nasional Penelitian Arsitektur-Metoda dan Penerapannya Seri. Vol. 2. 2009

Moeliono, Ilya dan Djohani Rianingsih. 1996. Kebijakan dan strategi menerapkan PRA dalam Pengembangan Program. Driya Media. Bandung

Merta, $\quad$ Made. 2007. http// ejournal.unud.ac.id.

Naghib, Laila. 2005. “Pengembangan Industri Pariwisata dan Isu 
Ketenagakerjaan". Dalam Jurnal Komunika Vol 8 No 2 Tahun 2005.

Nuryanti, Wiendu.1993. Concept, Prespective and Challenges, makalah bagian dari Pemberdayaan Masyarakat Desa. Yogyakarta : UGM press

Rahayu,Emik. 2011 . Pengembangan Participatory Rural Appraisal sebagai Metode Pembangunan Pariwisata Berbasis Masyarakat, Gemawsiata Vol 9. Semarang.

Rochdyanto, Saiful. 2000. Langkahlangkah Pelaksanaan Metode PRA. Makalah ToT PKPI. Yogyakarta

Soemarmo. 2010. "Desa Wisata" diakses

melalui http://marno.lecture.ub.ac. id tanggal 10 pukul 22.30 WIB.

Soetomo. 2007. Filsafat Pariwisata. Makalah disampaikan pada Pendidikan dan Pelatihan Peningkatan Mutu Tenaga Kepariwisataan 22-26 Mei 2007. STIEPARI Semarang.

Sastrayuda, Gumelar S (2010) ,Handout kuliah Concept Strategi Pengembangan dan Pengelolaan Resort and Leisure. Bandung

Sugiarti, R. 2004. Solusi dan Aplikasi Usaha Pembangunan Pariwisata berbasis Masyarakat, Makalah disampaikan dalam seminar Pembangunan Pariwisata Berbasis Masyarakat. 18 Februari 2004. Semarang
Undang-Undang RI No 10 tahun 2009 tentang Kepariwisataan

United Nations Conference on Trade and Development (UNCTAD). 2007. Trade and Development Implications Of International Tourism for Developing Countries.

(http://wwww.unctad.org/sections/ditc tncdb/docs/ditc_tncd_compdip0017 en.pdf, diakses 10 oktober 2011. 